Semina $\square \quad \mathrm{Nr} 13$

Scientiarum 2014

s. $153-175$

Paweł Stacewicz

\title{
O związkach matematyki z filozofią na przykładzie projektu Archipelag Matematyki
}

Niniejszy artykuł ma charakter wielce nietypowy. Nie dotyczy bowiem żadnego specjalistycznego zagadnienia (lub kręgu zagadnień) z dziedziny filozofii, lecz pokazuje na przykładzie konkretnego projektu (oraz pewnej próbki zaczerpniętych zeń materiałów), w jaki sposób popularyzując matematykę, można wykorzystywać filozofię. Innymi słowy: w jaki sposób filozofia i jej historia mogą dopomóc w przyswojeniu pewnych treści matematycznych.

Naukowo-popularyzatorski projekt, do którego będziemy się dalej odwoływać, nosi nazwę „Archipelag Matematyki” i został zrealizowany w Politechnice Warszawskiej. Obecne w nim treści filozoficzne mają charakter trojaki: po pierwsze, są to omówienia pewnych ogólnych poglądów na naturę poznania matematycznego i obiektów matematycznych (jak platonizm czy instrumentaizm), po drugie, sa to prezentacje poglądów pewnych historycznych postaci, które będąc filozofami, budowały fundamenty matematyki (jak Arystoteles czy G. W. Leibniz), po trzecie, są to różne filozoficzne interpretacje pojęć matematycznych (jak zbiór, różniczka czy nieskończoność).

Autor artykułu był w zespole Archipelagu metodykiem odpowiedzialnym za opracowywanie i/lub recenzowanie treści z dziedziny logiki, teorii mnogości oraz analizy matematycznej. Z racji swojego filozoficznego wykształcenia wprowadził do projektu szereg elementów z pogranicza matematyki, filozofii i nauk humanistycznych - co zgadza się dobrze z szerokim celem projektu: opowiedzieć o matematyce w sposób wykraczający poza nią samą. 
Bardzo ważny element artykułu stanowią próbki oryginalnych materiałów o tematyce filozoficzno-matematycznej (ich twórca jest autor tekstu, a są one zawarte w rozdziale 2). Próbka pierwsza dotyczy ważkich matematycznie idei G. W. Leibniza, zaś druga - niektórych filozoficznych pytań związanych z teorią mnogości. W przekonaniu autora prezentacja tego rodzaju przykładów jest najlepszym sposobem zapoznania czytelnika z idea matematycznego Archipelagu oraz naturą eksponowanych w nim związków między matematyką i filozofią.

\section{Archipelag Matematyki}

\subsection{Koncepcja i cele}

Ujmując rzecz filozoficznie, pod nazwą,Archipelag Matematyki” kryja się dwa byty. Z jednej strony oznacza ona innowacyjny projekt edukacyjny, który był realizowany w latach 2011-2014 na Wydziale Matematyki i Nauk Informacyjnych Politechniki Warszawskiej $^{1}$. Z drugiej strony zaś, określa się nią finalny produkt ww. projektu, czyli internetowe i multimedialne zarazem środowisko poznawania matematyki - jej źródeł, idei i zastosowań. Środowisko to jest przeznaczone przede wszystkim dla uczniów szkół średnich, ale prezentowane w nim treści wykraczają (niekiedy dość znacznie) poza materiał szkolny. Wykraczają także poza samą matematykę - np. w kierunku filozofii, historii i nauk przyrodniczych ${ }^{2}$.

W niniejszym artykule będziemy koncentrować się raczej na wspomnianym środowisku niż na warunkującym jego powstanie

1 W projekcie uczestniczyli zarówno pracownicy Wydziału, jak i osoby oraz firmy zewnętrzne. Ci pierwsi pełnili funkcje organizatorów, pomysłodawców, metodyków i recenzentów, podmioty zewnętrzne natomiast zajmowały się realizacją opracowanych wstępnie materiałów w formie dostosowanej do specyfiki współczesnych mediów (głównie internetu). Trzecią grupa, która aktywnie uczestniczyła w projekcie, byli nauczyciele i uczniowie testujaccy (a niekiedy i recenzujaccy) kolejne wersje realizowanych materiałów.

2 Obecnie środowisko to jest dostępne w sieci pod adresem www.archipelagmatematyki.pl. 
projekcie. Mimo to, na początek, warto opisać podstawowe cele, jakie przyświecały pomysłodawcom, a następnie uczestnikom całego przedsięwzięcia.

Cel pierwszoplanowy to dotarcie do grupy uczniów średnio matematycznie uzdolnionych i średnio zainteresowanych matematyką (mówiąc swobodnie: chcieliśmy dotrzeć do tych, którzy jeszcze nie wiedza, że lubią matematykę; a jest ich większość). Realizacja wspomnianego celu wymusiła pewien kompromis: z jednej strony trzeba było zachować właściwą matematyce abstrakcyjność i ścisłość, z drugiej zaś należało poświęcić suchy wykładowy formalizm na rzecz form bardziej poglądowych (animacji, filmów, komiksów czy gier). Ów „swobodny formalizm” miał zaciekawić, przemówić do wyobraźni, a przede wszystkim nie odstraszyć tych, którzy stykali się dotychczas z mniej atrakcyjnym obliczem „królowej nauk".

Przyjmując dodatkowe założenie, że docelowa grupa uczniów gustuje raczej $\mathrm{w}$ tematach niematematycznych (w tym humanistycznych), zdecydowano się pokazać, że matematyczne pojęcia przenikają najprzeróżniejsze dziedziny życia, a niektóre przynajmniej z ich źródeł maja charakter ogólno-kulturowy (np. filozoficzny). Inny aspekt tego rodzaju podejścia to zwrócenie uwagi na niewątpliwy fakt zagadkowości matematyki; ukazanie pojęć i twierdzeń, o których „się filozofom nie śniło”, jak np. paradoksy nieskończoności czy nieobliczalność pewnego rodzaju liczb.

Z prezentacją pobudzających ciekawość zagadek idzie w parze kolejny cel twórców projektu: maksymalna aktywizacja ucznia. Niech uczeń sam odkrywa matematyczne światy, niech sam wybiera ścieżki, którymi chce podążyć, niech rywalizuje z innymi i staje się lepszym od nich odkrywca Archipelagu. Realizacji tego celu służy ogólna koncepcja Archipelagu jako multimedialnej, internetowej gry $^{3}$.

3 W formie przypisu należy zwrócić uwagę na inny jeszcze, całkiem prozaiczny, cel projektu. Otóż, jak wynika z doświadczeń dydaktycznych pracujaccych nad Archipelagiem metodyków, istnieje współcześnie poważna luka między przeciętnym zakresem wiedzy szkolnej a materiałem wymaganym na studiach (zwłaszcza tech- 


\subsection{Wirtualny świat internetowej gry}

Zgodnie z ogólną koncepcją i celami dydaktycznymi metodyków Archipelag Matematyki jest multimedialną grą, w której zdobywa się punkty, realizuje się pewne zadania i misje, buduje się swoja pozycję wśród innych graczy, uzyskuje się przywileje zamieszczania własnych treści itp. Gra toczy się w wirtualnym świecie Archipelagu, który nie jest zamknięty, lecz może (i powinien) być rozbudowywany przez aktywnych uczestników gry ${ }^{4}$.

Wirtualny świat Archipelagu składa się z sześciu wysp reprezentujących różne działy matematyki. Są to: Wyspa Liczb, Wyspa Algebry, Wyspa Logiki i Teorii Mnogości, Wyspa Analizy Matematycznej, Wyspa Geometrii oraz Wyspa Matematyki Dyskretnej. Na każdej z nich znajduja się pewne charakterystyczne miejsca obfitujące w matematyczne treści, np. Pałac Gubernatora (gdzie można spotkać duchy słynnych uczonych z przeszłości, w tym filozofów), Akademia (gdzie są dostępne specjalistyczne kursy i skrypty), Kino (gdzie sa wyświetlane filmy o matematyce i matematykach), Pawilon Osobliwości (gdzie można poznać niezwykłe matematyczne fakty, których tajemniczość jest nierzadko cechą przykuwajaca uwagę filozofów).

Naturalną czynnością gracza, który trafi do świata Archipelagu, jest wędrowanie. Gracz porusza się między wyspami, a gdy zaciekawi go pewien temat (omawiany przeważnie na określonej wyspie), musi pokonać trasę zaprojektowaną przez twórców gry. Nie są to zatem wędrówki całkiem spontaniczne.

Przykładowo: uczeń zainteresowany logicznym rachunkiem zdań zostanie „skierowany” na Wyspę Logiki i Teorii Mnogości.

nicznych). Z tego powodu pośród treści prezentowanych na platformie znajdują się i szeregi liczbowe, i pochodne, i całki, a nawet pewne wstępne informacje o równaniach różniczkowych.

${ }_{4}$ W pierwotnym zamierzeniu Archipelag miał przypominać - zarówno od strony graficznej, jaki i ze względu na naczelną ideę budowy własnego świata - szeroką znaną grę internetową Minecraft. Owo podobieństwo, choć tylko powierzchowne (bo w Archipelagu chodzi przede wszystkim o poznawanie matematyki), miało stanowić element przyciagający uczniów. 
Tam będzie musiał odwiedzić Akademię i przeczytać kurs „Logiczne Preliminaria", następnie zostanie zaproszony na Arenę Gier Logicznych, gdzie przystapi do gry „Zero czy jeden?”, po jej zaliczeniu ponownie trafi do Akademii, gdzie zapozna się z kursem „Tautologie", a na koniec zasiądzie w kinie, gdzie obejrzy film (prawie fabularny) o dowodzeniu metodą nie wprost. W efekcie pokonania opisanej trasy gracz wzbogaci swoje konto punktowe, a być może też zdobędzie pewne odznaczenia i podwyższy swoją aktualną kategorię odkrywcy.

Z metodyczno-dydaktycznego punktu widzenia podstawowym rodzajem aktywności archipelagowych wędrowców powinno być przyswajanie matematycznych treści. Treści te sa podzielone na porcje, nazywane technicznie jednostkami treści, i rozmieszczone w odpowiednich miejscach poszczególnych wysp. Ze względu na ogólną formę (ogólną - bo w dużej mierze niezależną od sposobu realizacji) obecne w Archipelagu jednostki można podzielić na następujace kategorie ${ }^{5}$ :

1. sfilmowane wywiady ze znanymi matematykami lub innymi naukowcami, wykorzystującymi w swoich badaniach narzędzia matematyczne (są wśród nich filozofowie),

2. animowane biografie słynnych matematyków,

3. krótkie filmy o ciekawych dowodach matematycznych i technikach dowodzenia,

4. multimedialne prezentacje niezwykłych faktów matematycznych,

5. prezentacje zastosowań matematyki,

6. minigry służące przyswajaniu różnych matematycznych pojęć,

7. internetowe kursy i testy poświęcone wybranym działom matematyki,

5 Ponieważ Archipelag Matematyki jest pomyślany jako świat otwarty (rozbudowywany stopniowo przez aktywnych uczestników gry), obecne w nim jednostki treści sa pewną wstępną i tymczasową propozycja, przygotowaną głównie przez zespół projektu (choć już zdarzają się wyjątki - to znaczy materiały opracowane przez uczniów i nauczycieli). 
8. tzw. mat-wywiady, czyli nagrane (lub tylko spisane) rozmowy ze zwykłymi ludźmi o ważnych pojęciach matematycznych (prowadzone w stylu sokratejskim - o czym dalej),

9. czaty z duchami, czyli nieformalne rozmowy z duchami słynnych uczonych z przeszłości (którzy byli niekiedy także filozofami).

\subsection{Filozoficzna zawartość Archipelagu}

Przeważająca część zawartości wirtualnego świata Archipelagu ma, rzecz jasna, charakter matematyczny, ale przygotowujac tę zawartość, przyjęto założenie, że matematyka nie jest pośród innych nauk „samotną wyspą, a do dobrego zrozumienia większości jej pojęć niezbędna jest znajomość ich źródeł i interpretacji. Próbując ukazać owe źródła i interpretacje, sięgnięto po filozofię - zarówno jej historię, jak i pewne ogólne rozważania metodologiczne. Filozofia zatem została potraktowana przez twórców Archipelagu jako ważny dodatek do matematycznego meritum.

Filozoficzna zawartość Archipelagu grupuje się w trzech obszarach, „rozproszonych” po różnych wyspach wirtualnego świata. Po pierwsze, sa to elementy splecionej z matematyka historii filozofii - splecionej przeważnie za sprawą konkretnych osób, które łączyły w swoich badaniach matematykę z filozofią (jak chociażby Kartezjusz czy Leibniz). W ramach tego obszaru wyłania się niezwykle ważne pytanie o filozoficzne inspiracje pewnych odkryć matematycznych, np. kodu binarnego odkrytego przez Leibniza (zob. pkt 2.1.) czy Turingowskiego modelu maszyn cyfrowych. Po drugie, ważne miejsce w Archipelagu zajmuje refleksja o naturze obiektów matematycznych i poznania matematycznego. $\mathrm{Na}$ plan pierwszy wybija się tu istotne i mocno osadzone w historii filozofii napięcie między platonizmem i arystotelizmem. Po trzecie wreszcie, przy okazji prezentowania niektórych tematów sa stawiane pewne pytania filozoficzne. Okazję do ich rozpatrzenia stanowią zarówno tradycyjne, jak i bardziej współczesne pojęcia matematyczne; do pierwszych zalicza się pojęcie nieskończoności, do drugich - pojęcie obliczalności. 
Wymienione w poprzednim akapicie zagadnienia znajdują swoje odzwierciedlenie w konkretnych materiałach, które już są dostępne na platformie Archipelagu (ich próbkę przedstawimy w kolejnym rozdziale).

Sa to: a) spotkania, rozmowy i czaty z duchami wielkich filozofów lub filozofujących matematyków (np. Heraklita, Arystotelesa, Leibniza i Cantora), b) specjalistyczne kursy obejmujace pewne zagadnienia filozoficzne (np. matematyczny platonizm, formalizm, instrumentalizm, istota metody dedukcyjnej), c) parasokratejskie dialogi ze zwykłymi ludźmi o pojęciach matematycznych (np. z rolnikiem o zbiorach, z elektrykiem o indukcji, z księgowym o liczbach nieobliczalnych). Pomysłodawca i współautorem prawie wszystkich materiałów tego typu jest autor niniejszego artykułu.

\section{Przykładowe materiały o tematyce filozoficznej}

W niniejszym podrozdziale zostaną przedstawione tekstowe wersje materiałów, które w nieco innej formie są dostępne na platformie Archipelagu. Wybrane przykłady obrazuja dobrze typowa dla omawianego projektu strategię łaczenia matematyki z filozofia; zgodnie z nią każda próba zestawienia wymienionych dyscyplin ma być i zaskakujacca, i inspirująca. Jako autor przedstawionych tekstów mam nadzieję, że okażą się one interesujące same w sobie, a nie tylko jako próbka materiałów obrazujących filozoficzne aspekty Archipelagu.

\subsection{Czat z duchem G. W. Leibniza}

Pierwszy przykład pochodzi z Wyspy Analizy Matematycznej, na której odbył się zarejestrowany przez media Archipelagu czat z duchem G. W. Leibniza. W trakcie owej nieformalnej rozmowy duch Leibniza rozprawia o metafizyce, rachunku różniczkowym, maszynach liczących, programie Calculemus i sztucznej inteligencji. Podkreśla kilkukrotnie filozoficzne korzenie swoich matematycznych odkryć. 
A oto i zapowiadany tekst:

prowadzacy:

Witamy. Otwieramy czat z naszym gościem, Wilhelmem Gotfriedem Leibnizem, niezwykle wszechstronnym uczonym XVII-wiecznym. Wielce zasłużonym i dla matematyki, i dla filozofii. Znawcy przedmiotu zwykli mawiać, że byt to ostatni $z$ wielkich, którzy wiedzieli wszystko.

\section{leibniz:}

Witam i ja. Dziękuję z całego ducha - bo to z duchem leibnizjańskim będziecie Państwo debatować - za tak ujmująca prezentację. Wypada mi potwierdzić słowa prowadzącego. Faktycznie, parałem się za życia mnóstwem rzeczy: od kronikarstwa i bibliotekarstwa, przez matematykę z inżynieria, aż do abstrakcyjnej filozofii. Myśli moje dojrzewały w rozlicznych dyskusjach, które odbywałem osobiście bądź listownie. Dyskusja to był mój żywioł. W formie internetowej jednak nie dyskutowałem jeszcze i to będzie mój debiut.

Czekam niecierpliwie na pierwsze pytanie.

kacper:

Zapytam na początek banalnie. Która z dziedzin czy też dyscyplin, bo studiował ich Pan wiele, pochłaniała Pana najbardziej?

\section{leibniz:}

Pytanie może i banalne, lecz odpowiedź niełatwa. Odpowiem nie do końca jednoznacznie. Po pierwsze: była to matematyka z logika. Po drugie: filozofia z metafizyką na czele. Po trzecie: inżynieria, w służbie matematyki jednak - inżynieria, powiedzielibyśmy dzisiaj, informatyczna. Bo, jak wiecie, interesowały mnie maszyny liczące.

\section{dyletant:}

A co to jest - pytam jako filozoficzny dyletant - ta filozoficzna metafizyka? 


\section{leibniz:}

Wolałbym nie rozmawiać dziś o filozofii, bo czat zaanonsowano mi jako matematyczny. Ale skoro Pan pyta, krótko odpowiem. Metafizyką nie jest oczywiście sfera rozmyślań nad duchami czy innymi sprawami nadprzyrodzonymi, jak niektórzy sądzą, a nawet piszą. Jest to pewien dział nauki, według mnie bardzo ścisłej, który ma odsłonić ukrytą strukturę świata. Nazwijmy go meta-światem, czyli światem skrytym pod powierzchnią zjawisk.

\section{dyletant:}

Czyli byłby to jakiś rodzaj fizyki, bardzo abstrakcyjnej fizyki, która bada najgłębsza, ukrytą przed oczami, mikrostrukturę świata?

\section{leibniz:}

Wręcz przeciwnie. Fizyka bada świat, schodząc oczywiście w jego głąb, a metafizyka meta-świat. Fizyka stosuje eksperyment, metafizyka myślową spekulację, nierozerwalnie splecioną z logika. Fizyka bada bardzo specjalne rodzaje zjawisk, dajmy na to zjawisko tęczy, a metafizyka chce dojść czysto rozumowo do bardzo ogólnych praw rządzących wszystkim. Mówiąc górnolotnie: pragnie dociec praw rządzących całym bytem.

\section{dyletant:}

Trochę to mętne, ale mniej więcej rozumiem. A mógłby Pan podać jakieś przykłady praw metafizycznych, czyli praw - jak Pan mówi-maksymalnie ogólnych?

\section{leibniz:}

Proszę bardzo. Jedno prawo wywodzi się z logiki. Zwie się je zasadą niesprzeczności. Głosi ona, że niczemu nie może przysługiwać w danej chwili pewna cecha i zarazem cecha przeciwna.

Inna zasada, sformułowana zreszta przeze mnie, to tzw. zasada ciągłości. Głosi ona, że zjawiska tworzą szeregi ciągłe; może ich być nieskończenie wiele i mogą różnić się od siebie dowolnie mało. Dobry przykład to barwy postrzegane w zjawisku tęczy. Ale także ludzie, cha- 
rakteryzowani pod jakimś kątem, na przykład pod kątem szybkości liczenia.

\section{prowadzacy:}

Nie wiem, czy słusznie, lecz wyczuwam, że wypowiadając ostatnie zdanie i przytaczając chwilę wcześniej zasadę ciagłości, Gość nasz chciałby zakończyć wątek filozoficzny i przejść do matematycznego... Czy tak?

\section{leibniz:}

Właśnie tak. Podkreślę jednak, że u mnie, tj. w moim umyśle, matematyka jest nierozerwalnie spleciona z filozofia. Teorie metafizyczne, np. moja monadologia, były inspirowane matematycznie; odkrycia matematyczne z kolei, np. te zwiąane z pochodnymi i całkami, były często wynikiem przemyśleń filozoficznych.

\section{bynio:}

W takim razie ciekawi mnie, jakie przemyślenia stały za odkryciem rachunku różniczkowego? Bo wszyscy wiemy, że rozwijał go Pan równolegle z Newtonem...

\section{leibniz:}

Tak. Interesowała mnie rzecz następujacca. Jeśli zasada ciagłości jest słuszna - a jej słuszność widać dobrze w dziedzinie liczbowej, gdzie kolejne liczby rzeczywiste różnią się od siebie nieskończenie mało - a więc, jeśli jest słuszna, to pojawia się pytanie o to, co dzieje się na styku dwóch wielkości, które różnią się od siebie nieskończenie mało.

Mówiąc zaś konkretniej: interesowało mnie, jak nieskończenie mały przyrost pewnej wielkości (powiedzmy x) wpływa na przyrost innej wielkości, zależnej od tej pierwszej (powiedzmy y)? Czy tempo wzrostu igreków wyraża się jakimś wzorem, i czy wzór ten daje się odtworzyć na podstawie wzoru zależności igreków od iksów, np. $\mathrm{y}=\mathrm{x}^{\wedge 3}$ ?

Wiedziałem, że całe zagadnienie można interpretować graficznie, rysując wykresy zmienności igreków i nanosząc na nich styczne, ale wiedząc to szukałem rozwiązań rachunkowych... 
bynio:

Czyli mówiąc dzisiejszym językiem, interesowało Pana zagadnienie pochodnej funkcji. A rozwiazanie rachunkowe to jakby schematyczne reguły obliczania pochodnych różnych funkcji...

\section{leibniz:}

Tak jest. Udało mi się opracować schematyczny, algorytmiczny rachunek pochodnych. Podałem wzory na pochodne różnych funkcji podstawowych, a także reguły obliczania pochodnych sumy, różnicy, iloczynu itd. To bardzo ważny rachunek.

prowadzacy:

Dopowiem tylko, że z rachunkiem pochodnych, czyli rachunkiem różniczkowym, powiązał nasz Gość rachunek jakby odwrotny, czyli całkowy. Pokazał, jak dla danej funkcji tempa wzrostu, znajdować funkcje pierwotne, tj. funkcje, dla których takie, a nie inne tempo wzrostu odnotowaliśmy. Tu też opracował sprytny rachunek. Dodam jeszcze, że wprowadzone przez niego oznaczenia, np. znany Państwu wężyk na oznaczenie całkowania i słynne deiksy, obowiązują do dziśs.

leibniz:

Dziękuję Panu, znakomicie i krótko Pan to objaśnił.

$n n$ :

A czy to prawda, że wynalazł Pan maszynę całkującą?

\section{leibniz:}

No nie... Taki całkiem genialny to nie byłem. Faktycznie jednak świat maszyn i obliczeń mechanicznych mnie fascynował. Zbudowałem mechaniczna machinę licząca, która potrafiła dodawać, odejmować, mnożyć i dzielić. Był to jakby kalkulator na korbkę.

Ale znowu: żeby nie powstały tu jakieś niedomówienia. Pierwszy w tej materii był Blaise Pascal. Ja po prostu ulepszyłem jego maszynę, tak aby zamiast samych dodawań i mnożeń była w stanie wykonywać działania względem nich odwrotnie, czyli odejmować i dzielić. 
$n n$ :

Ale marzył Pan o maszynach całkujących i różniczkujących...

\section{leibniz:}

Ba! Nie tylko o takich. Marzyłem o maszynach myślących, zdolnych algorytmicznie rozwiązywać wszelkie zadania. Zaprojektowałem nawet medal z odpowiednią inskrypcją: Temu, co przewyższy człowieka. Nazwałbym go dziś pierwszym w dziejach medalem dla robota...

netbot:

I co? Wręczyłby Pan go komuś, czy raczej czemuś?

\section{leibniz:}

A kto zadał pytanie: człowiek czy internetowy bot? Pewnie musiałbym popytać dłużej, żeby rozstrzygnaćc...

Ale mówiąc poważnie: z uwaga śledzę współczesne badania nad sztuczną inteligencją i naprawdę robi to wrażenie. Macie maszyny wnioskujące, konwersujące, uczące się... Używałem także programu komputerowego, który potrafił całkować symbolicznie, i to funkcje o wiele bardziej złożone niż te, którymi ja się zajmowałem. Mój duch promienieje.

\section{prowadzacy:}

Duch promienieje najzupełniej słusznie. Zwłaszcza, że dokonał Pan jednego jeszcze odkrycia, które predestynuje Pana do zaszczytnego miana „Ojca informatyki”. Czy uczestnicy czatu wiedzą jakiego? Dla ułatwienia dodam, że było to odkrycie matematyczne.

$n n$ :

Logika dwuwartościowa?

prowadzacy:

Nie, ale blisko...

bynio:

Kod binarny? 


\section{leibniz:}

Brawo! Chodzi o pozycyjny system binarny. Jeszcze w latach młodzieńczych wpadłem na pomysł zapisywania liczb za pomocą dwóch tylko symboli, 0 i 1. Wydawało mi się, że jest to sposób najdoskonalszy, bo angażujacy najmniejszą możliwą liczbę symboli.

Od zapisów zero-jedynkowych aż biła liczbowa prostota. Dodatkowo fascynowała mnie myśl, że zapisami binarnymi interesowali się już starożytni Chińczycy; dowiedziałem się sporo z ich pism.

Stopniowo rozwijałem swój pomysł: opracowałem mechaniczne schematy obliczeń na liczbach binarnych, a także zaprojektowałem hipotetyczną maszynę do ich wykonywania.

metys 12:

Ale maszyna taka nie powstała?

\section{leibniz:}

Nie. Pozostała w sferze czystego projektu. Powiem też zupełnie szczerze, że nie miałem pojęcia, iż kod binarny stanie się później swoistym lingua characteristica komputerów. Ja o takim uniwersalnym języku marzyłem, rozwijałem nawet pewne idee matematyczno-logiczne (tzw. algebrę pojęć), nie podejrzewałem jednak, że to właśnie kod binarny odegra w przyszłości rolę uniwersalnego nośnika informacji.

\section{metys 12:}

Miał Pan jednak doskonała intuicję co do roli liczb i obliczeń w rozwiązywaniu wszelkich problemów, nie tylko matematycznych. To Pan chyba rzucił hasło CALCULEMUS, czyli po polsku: POLICZMY. Mógłby Pan powiedzieć kilka słów na ten temat.

\section{leibniz:}

$\mathrm{Z}$ wielką chęcią. Ideę CALCULEMUS realizują dzisiejsze komputery, które sa przecież maszynami liczącymi - bardzo wyrafinowanymi wprawdzie, lecz tak naprawdę liczącymi. Oto ta idea w punktach, dostosowanym swoim brzmieniem do dzisiejszych realiów.

1. Wybierzmy problem do rozwiązania (niekoniecznie matematyczny); 
2. Zakodujmy problem symbolicznie, w postaci zrozumiałej dla maszyny;

3. Zamieńmy symbole na liczby (tak naprawdę maszyna zrobi to automatycznie);

4. Pozwólmy maszynie dokonać odpowiednich obliczeń, czyli przekształcić liczby reprezentujące dane w liczby wynikowe;

5. Zamieńmy liczby wynikowe na symbole;

6. Zinterpretujmy symbole jako rozwiązanie problemu.

To wszystko. I to wszystko - no może poza punktem 6. - wykonują za Was dzisiejsze komputery. Ponieważ jądrem całej procedury jest punkt 4., procedurę można posumować jednym słowem POLICZMY, czyli po łacinie CALCULEMUS.

bynio:

Może i jądrem procedury jest punkt 4., ale ktoś musi zrealizować punkty pozostałe. W szczególności musi wybrać problem, zakodować go symbolicznie, a na koniec zinterpretować „wyplute” przez maszynę symbole... Moim zdaniem, bez człowieka ani rusz.

\section{leibniz:}

Tu nie byłbym taki pewien. Postęp w dziedzinie automatyzacji ludzkich czynności umysłowych trwa. Mój duch nie jest tu specjalista, lecz obserwatorem. Być może istnieje nie tylko uniwersalny język liczbowego kodowania problemów (powiedzmy, że binarny), lecz nadto uniwersalny rachunek symboliczny, pozwalający rozwiązywać mechanicznie wszelkie problemy. Tego nie wiem.

\section{prowadzacy:}

Proszę Państwa. Dyskusja rozgorzała na dobre. Proszę zauważyć, jak zupełnie niepostrzeżenie przeszliśmy od metafizyki, przez czysta matematykę, do maszyn działających w oparciu o zasady matematyki, a na koniec do pewnych filozoficznych pytań dotyczących tych maszyn. Być może dotarlibyśmy w inne jeszcze rejony...

Pora jednak kończyć, co niniejszym muszę uczynić. Dziękuję wszystkim za udział i zapraszam do rozwiązania nietrudnego testu końcowego. 


\subsection{Radiowy dialog $\mathrm{z}$ rolnikiem o zbiorach}

Kolejny przykład materiału matematyczno-filozoficznego pochodzi z wyspy Logiki i Teorii Mnogości, gdzie został zamieszczony jeden z matematycznych dialogów (tzw. mat-wywiadów) reporterki archipelagowego radia MAT ze zwykłymi ludźmi. Napotkany przez reporterkę rolnik stara się „przyłożyć” swoją wiedzę o zbiorach rolniczych do tradycyjnych pojęć teoriomnogościowych. W trakcie rozmowy rolnik odkrywa pojęcia: zbioru, równoliczności zbiorów i nieskończoności. Nierzadko też ociera się o kwestie filozoficzne.

A oto i zapowiadany tekst dialogu:

\section{[Wstęp]}

Tym razem reporterka radia MAT zapuszcza się na wieś, by porozmawiać o teorii mnogości. Widzimy ją tuż przy rozległym polu pszenicy, gdzie pracują maszyny: traktor i kombajn. Reporterka podchodzi do nadzorującego prace rolnika. Mówi doń głośno, a właściwie woła, przekrzykując warkocące maszyny:

- Dzień dobry! Jak tam zbiory...?

- Kiepsko. Susza.

- To niedobrze. Ale może chcielibyście Panowie porozmawiać o teorii zbiorów...?

- Że niby co? Jak teoretycznie dużo zebrać...?

- Nie. O matematycznej teorii zbiorów.

- Eee, to chyba nie... My wszyscy dawno po szkole.

- Ale Panowie, mi wtaśnie o to chodzi. Jestem z radia $i$ nagrywam wywiady ze zwyktymi ludźmi o pojęciach matematycznych. Panowie mi jak najbardziej pasujecie...

- Chwila... Bo strasznie trzeba krzyczeć. Wyłączymy kombajn...

Mężczyzna daje znak koledze, by wyłączył maszynę. Gdy silnik przestaje hałasować, pyta:

- To jak Pani mówi? Że z radia?

- Tak. Matematycznego. I chcę namówić Panów na rozmowę o zbiorach. 
- Czyli na czasie...

- Jak najbardziej. Choć w pewnym sensie zbiór to obiekt ponadczasowy.

- (???)

- Już wyjaśniam... Mówicie Panowie, że macie kiepskie zbiory. Dla matematyków jednak sq to takie same zbiory jak wszelkie inne. Dla nich zbiór, inaczej mnogość, to każda grupa przedmiotów o wspólnej własności. Na przykład: mogliby zdefiniować i oznaczyć literka A zbiór wszystkich ziaren pszenicy o takiej a takiej wadze; ale bytby to tylko przyktad, przyktad czegoś, co spetnia pewne ogólne prawa.

- Noo... Konkretne to to nie jest?

- No nie. Bo zbiór to przedmiot abstrakcyjny...

Myślimy sobie o jakiejś cesze konkretnych przedmiotów, np. kulistości. I abstrahujac od innych cech tych przedmiotów, powotujemy do życia inny jakby-przedmiot: zbiór rzeczy kulistych.

- Właściwie to po co, jak Pani mówi, powołujemy?

- Wtaściwie to dla wygody. Czyniac coś zbiorem, czynimy to coś przedmiotem ogólnej teorii. Takiej teorii, której wyniki pozostaja stuszne dla wszelkich zbiorów - również takich, które odpowiadaja cesze kulistości.

- Jeśli jednak mamy się dogadać, to musimy konkretniej...

- Okay. To jakbyście Panowie policzyli, ile elementów ma dany zbiór?

- Właściwie sama Pani powiedziała: policzyli. Liczymy element po elemencie, np. ziarnko po ziarnku pszenicy, i wychodzi nam, ile jest wszystkich. Trochę to oczywiście potrwa, ale do wyniku dojdziemy.

- Czyżby? A co wtedy, gdy zbiór jest nieskończony?

- No nie... Miało być konkretnie... A tu znowu: nieskończoność.

Chętnie bym zobaczył nieskończenie wielki wór pszenicy.

- Do tego spokojnie dojdziemy. Na poczatek jednak, pomyślcie Panowie, jak można ustalić bez liczenia - bo nie sposób przecież liczyć w nieskończoność - że dwa zbiory maja tyle samo elementów. Ni mniej, ni więcej-tylko tyle samo.

- Bez liczenia?

$-B e z$.

- Nie podpuszcza nas Pani? 
- W żadnym wypadku. W jaki sposób, na przyktad, stwierdzicie Panowie - o ile przejdziemy od zbiorów pszenicy do jej spożycia-że na dobrze zastawionym stole leży tyle samo widelców co noży.

- Tutaj akurat jest prosto. Jeśli ktoś dobrze poukładał, to obok każdego widelca musi leżeć nóż.

- Czyli każdemu widelcowi musi odpowiadać dokładnie jeden nóż?

- No tak.

- No a tak samo można zrobić zawsze. Wystarczy stwierdzić, że kazdemu elementowi zbioru A odpowiada doktadnie jeden element zbioru B. Matematycy powiedzieliby: istnieje funkcja różnowartościowa przekształcajqca zbiór A na zbiór B. Jeśli znamy taka funkcję, nie musimy liczyć elementów - wiemy, że jest ich tyle samo w A co w B. Czy tak?

- Niby tak. Ale skąd mamy wiedzieć, co to za funkcja? I gdzie tu nieskończoność?

- Powoli. Funkcje znajduja matematycy: sq w tym równie dobrzy, jak Panowie w koszeniu. A nieskończoność pojawia się wtedy, gdy chcemy porównywać ze soba zbiory nieskończone.

- Na przykład?

- Na przykład zbiór liczb naturalnych $N$ (1, 2, 3 itd.) ze zbiorem liczb parzystych $P$ (2, 4, 6 itd.). Obydwa sa nieskończenie liczne, przy okazji jednak - równoliczne. A równoliczne sq dlatego, że istnieje funkcja f przeksztatcajqca zbiór $N$ na $P$. Ma ona bardzo prosty wzór: $f(n)=2 n$. Przyktadowo: $f(1)=2$, czyli jedynce odpowiada dwójka, $f(2)=4$, czyli dwójce odpowiada czwórka i tak dalej.

- Czyli, według Pani, zbiory N i P sa tak samo liczne...?

- Nie tyle wedtug mnie, co wedtug naszych zasad.

- Tak na oko jednak, to bzdura! Liczb parzystych jest dwa razy mniej niż naturalnych.

- Na oko może i bzdura. Ale nasze oko kiepsko widzi nieskończoność...

Skoro zgodziliśmy się na „nożowo-widelcowa” metodę sprawdzania równoliczności, to musimy się zgodzić na równoliczność zbiorów $N$ i P.

- W takim razie, czy nie będzie tak, że wszystkie zbiory nieskończone sa tak samo liczne?

- Brawo! Wciagnęliście się Panowie w nasz abstrakcyjny temat. Ale nie. Tak nie jest! Nie wszystkie zbiory nieskończone sq równoliczne. 
- Bo?

- Bo, na przykład, zbiór liczb naturalnych nie jest równoliczny ze zbiorem liczb rzeczywistych, czyli wszelkich możliwych liczb dziesiętnych z częściq utamkowa, np. 1,75; 2,43, liczba Pi, itd. Liczb rzeczywistych-zgodnie z naszymi zasadami-jest więcej.

- Wypada chyba uwierzyć na słowo.

- W tej chwili nie macie Panowie innego wyjścia. Bo dowód wymaga trochę większej znajomości matematyki. Ale powiem Wam, że istnieje pewna niezwykle ciekawa zasada ogólna: każdy zbiór nieskończony jest mniej liczny niż zbiór wszystkich jego podzbiorów.

- Jak to podzbiorów?

- Ano tak: bierzemy jakiś zbiór złożony z konkretnych elementów - pierwszego, drugiego, trzeciego itd. Nastepnie grupujemy te elementy na wszelkie możliwe sposoby, np. sam pierwszy element, pierwszy z drugim, pierwszy z trzecim itd., nazywajac kazda taka grupe podzbiorem. Nastepnie liczymy podzbiory. Okazuje się, że zawsze będzie ich więcej niż elementów w samym zbiorze. A zatem: rodzina wszystkich podzbiorów danego zbioru jest bardziej liczna niż sam zbiór.

- Czyżby wynikało z tego, że istnieje nieskończenie wiele rodzajów nieskończoności?

$-B o$ ?

- Bo wydaje mi się, że możemy w nieskończoność tworzyć zbiory wszystkich podzbiorów. Najpierw rodzinę podzbiorów zbioru A, powiedzmy AA. Ma ona więcej elementów niż A. Potem rodzinę podzbiorów zbioru AA, powiedzmy AAA. Ma ona więcej elementów niż AA. I tak w nieskończoność.

- Gratulacje! Brawo! Spostrzegt Pan coś, co twórca teorii zbiorów, George Cantor, określit obrazowo jako otchtań nieskończoności. Nie przeraza to Pana?

- Czy ja wiem? Raczej niestrachliwe ze mnie chłopisko. A poza tym nasze „chłopskie” zbiory były i będą skończone.

- To fakt. A nasz wywiad także ma skończony czas. Krótko mówiac: musimy kończyć. Dziękuję bardzo za rozmowę.

- Dziękujemy i my. 


\section{Końcowe wnioski metodologiczne}

Na koniec chciałbym podzielić się z czytelnikiem garścią uwag metodologicznych, do których skłania uczestnictwo w opisanym projekcie. Uwagi te będa dotyczyć nauczania obydwu tytułowych dyscyplin, matematyki i filozofii, w taki sposób jednak, by druga z nich jak najwięcej na tym skorzystała.

Uwagi będą koncentrować się wokół dwóch pytań:

1. W jaki sposób w nauczaniu matematyki wykorzystywać filozofię?,

2. Jak uczyć filozofii, wykorzystując matematykę (a także inne nauki ścisłe)? ${ }^{6}$.

Czastkowej odpowiedzi na pytanie pierwsze dostarcza drugi z opisanych wyżej przykładów. Jego forma dialogowa powinna nasunąć skojarzenie z dialogami Platońskimi, i zawartą w nich sokratejską metodą stopniowego wydobywania wiedzy z rozmówcy poprzez podsuwanie trafnych skojarzeń i pytań (tzw. metoda majeutyczna). Uważam, że dydaktycy matematyki powinni częściej stosować tę metodę, bazując na nabytych i wrodzonych intuicjach ucznia (zakorzenionych niekiedy w języku potocznym). Stosując ja, mogliby powoływać się (nawet $\mathrm{w}$ formie ciekawostki) na jej filozoficzny, sokratejsko-platonski, rodowód. Dodam jeszcze, że w Archipelagu matematyki nie brakuje materiałów zorganizowanych $\mathrm{w}$ taki właśnie sposób, a wiele z nich przynależy do kategorii mat-wywiadów (zob. pkt 2.2.).

Kolejna „filozoficzna” wskazówka dla dydaktyków matematyki wiąże się również z pytaniami - tym razem jednak chodzi o motywowanie uczniów do samodzielnego stawiania pytań filozoficznych. Nie tylko matematycznych, związanych z taką czy inną defi-

6 Na marginesie pierwszego z pytań warto zauważyć, że uwzględnienie w omawianym projekcie filozofii było inicjatywą samych matematyków, a szczególnie kierującego całym przedsięwzięciem prof. Tadeusza Rzeżuchowskiego. Już sam ten fakt jest znaczący: okazuje się bowiem, że przedstawiciele innych dyscyplin, w tym tak - wydawałoby się - samowystarczalnych jak matematyka, pragną sięgać do filozofii. Kwestia kolejna to bardzo dobre przyjęcie filozoficznej zawartości Archipelagu przez nauczycieli (recenzujących niektóre materiały) oraz uczniów (testujaccych projekt). Na koniec zaś pewien akcent personalny: otóż w ostatniej fazie realizacji projektu funkcję głównego redaktora merytorycznego (a także specjalisty od pewnych spraw technicznych) pełnił filozof z wykształcenia: pan Adam Wasążnik. 
nicją lub metoda, lecz bardziej ogólnych. Oto sugestywny przykład: Czym jest liczba? i Czy naprawdę to wiemy? Niech uczeń wczuje się w ten problem, zestawi różne rodzaje liczb, pozna różne sposoby odpowiedzi... niech przekona się w ten sposób o otwartym charakterze matematyki, w której wciąż przecież konstruuje się nowe pojęcia, w tym nowe rodzaje liczb.

Przy okazji stosowania tego rodzaju metody warto podkreślać -i to ma już bezpośredni związek z historią filozofii - że historycznie rzecz biorąc, wiele matematycznych odkryć było inspirowanych pytaniami filozoficznymi (tak np. rozumował G. W. Leibniz; zob. pkt 2.1.).

Podążając tropem pytań, za sprawą których filozofia może przyczynić się do skuteczniejszego nauczania matematyki, dochodzimy do kwestii kolejnej. Otóż często przedstawia się matematykę jako narzędzie - narzędzie, które warto opanować po to, by móc poprawnie rozumować, formułować trafne przewidywania czy skuteczniej przekształcać świat. Innymi słowy zwraca się uwagę na bogate zastosowania matematyki. Wybierając taką strategię popularyzacji (a tak właśnie uczyniono w omawianym projekcie), przyjmuje się domyślnie, że świat wokół nas jest matematyczny. Ale dlaczego tak jest? Skąd wynika ta jego zdumiewająca cecha? Sa to najgłębsze pytania filozoficzne, którymi warto dopełnić prosty przekaz o mnogości zastosowań. Warto zachęcić ucznia (zwłaszcza humanistę) do sformułowania własnego stanowiska w tej sprawie (omawiając wcześniej typowe odpowiedzi Platona, Arystotelesa, Kanta i innych) i pokazać w ten sposób, że matematyki nie tylko trzeba się uczyć, ale warto także się nad nią zastanawiać.

Podsumujmy zatem: pozytywna rola filozofii w nauczaniu matematyki polega przede wszystkim na tym, że zachęca ona do stawiania pytań - pytań ukierunkowujących myślenie (metoda majeutyczna), pytań o istotę matematycznych pojęć oraz pytań o stosunek matematyki do świata.

Przejdźmy z kolei do pytania drugiego, w którym główny akcent pada na nauczanie filozofii, a nie matematyki ${ }^{7}$. Z uwagi na spe-

7 Mimo innego rozłożenia akcentów, trzeba zauważyć, że pytanie drugie pokrywa się po części z pierwszym. Dzieje się tak dlatego, że nauczanie matematyki 
cyfikę omawianego projektu (a także kończący poprzednie zdanie przypis) pytaniu temu poświęcę nieco mniej miejsca.

$\mathrm{Na}$ początek narzuca się uwaga następująca: gdyby chcieć zachować symetrię z układem wcześniejszych wniosków, to można by stwierdzić, że podobnie jak w nauczaniu matematyki pożądana wydaje się metoda majeutyczna, tak w nauczaniu filozofii winno się stosować metody matematyczne. To znaczy: precyzyjne definiowanie terminów, aksjomatyzację, formalne dowody itp. Do wniosku tego skłania nadto podobnie ogólny i abstrakcyjny charakter pojecć używanych w obydwu dyscyplinach (np. z jednej strony mamy byt, a z drugiej - liczbę).

Ponieważ powyższa uwaga jest bardzo ogólna, a jej rozwinięcie wymagałoby dalszego precyzowania, o jakie metody matematyczne chodzi, i które z nich można by z powodzeniem wykorzystać, proponuję rozpatrzyć na koniec trochę inny punkt widzenia, mocno zbieżny z przykładem z punktu 2.2. Mam na myśli taką metodę nauczania filozofii, która mimo zachowania wysokiego poziomu abstrakcji nawiązuje do konkretnych pojęć, metod i twierdzeń matematyki. Z grubsza idzie o metodę następujacca: (i) wychodzimy od matematycznego „konkretu”, którego opis nie pozostawia żadnych niedomówień (np. od Cantorowskiego pojęcia nieskończoności), (ii) omawiamy ów matematyczny punkt wyjścia w kontekście filozoficznym (np. przedstawiamy będące jego źródłem intuicje filozofów czy też stosujemy go do zilustrowania lub rozjaśnienia pewnych kwestii filozoficznych), (iii) jeśli pierwotne matematyczne definicje okazują się filozoficznie nieadekwatne, próbujemy je przeformułować (np. zmienić Cantorowskie ujęcie nieskończoności).

Metoda taka, choć opisana bardzo zgrubnie, ma dwie istotne zalety: zbyt spekulatywnych i dygresyjnie nastawionych filozofów przymusza do ścisłości wywodu, matematyków z kolei wyposaża w pewną ciekawą heurystykę (heurystykę filozoficzna) dochodzenia do nowych pojęć (a w rezultacie: nowych twierdzeń i nowych teorii). Owe dwie zalety, niekoniecznie związane z powyższą meto-

z wykorzystaniem filozofii jest jednocześnie pewną metodą przybliżania niektórych zagadnień filozoficznych. 
da, można uznać za kwintesencję wszelkich prób łączenia matematyki z filozofia.

\section{Summary}

\section{Tu powinien być jeszcze angielski tytuł tego artykułu}

Some new, philosophically inspired, methods of teaching mathematics are discussed in this paper. These methods are implemented and embedded in the virtual environment of learning and exploring mathematics, called officially Archipelago of Mathematics (available at www.archipelagmatematyki.pl). They seem to be effective due to different interconnections between mathematics and philosophy (both historical and contemporary).

After describing methodological assumptions, goals, methods and the structure of Archipelago, I present two, designed by me, examples of its contents: (1) quasi-internet chat with the ghost of G.W. Leibniz (on metaphysics, philosophical aspects of calculus, and artificial intelligence); and (2) radio-style interview with a farmer on the mathematical theory of sets and infinity. Presented materials show such a relationships between mathematics and philosophy like: philosophical origin of some mathematical concepts, philosophical implications of some math. ideas and theorems, heuristic function of philosophical discussions in mathematics.

Keywords: philosophy, mathematics, virtual world of mathematics, computing, infinity.

\section{Bibliografia}

Archipelag Matematyki (http://www.archipelagmatematyki.pl), multimedialne środowisko nauczania i poznawania matematyki.

Cafe Aleph (http://blog.marciszewski.eu/), akademicki blog dyskusyjny W. Marciszewskiego i P. Stacewicza, zawierajacy sporo materiałów z pogranicza matematyki i filozofii.

Davis P. J., Hersch R., Świat matematyki, Warszawa 1994.

Kordos M., Wyktady z historii matematyki, Warszawa 1994.

Mała encyklopedia logiki, red. W. Marciszewski, Wrocław 1988.

Marciszewski W., „Mathesis Universalis” na nasze czasy. Wktad Fregego, Cantora i Gödla, „Zagadnienia Naukoznawstwa” 2011, nr 4 (190), s. 139-152. 
Marciszewski W., Stacewicz P., Umyst - Komputer - Świat. O zagadce umystu z informatycznego punktu widzenia, Warszawa 2011.

Murawski R., Filozofia matematyki. Zarys dziejów, Warszawa 1995.

Peter R., Gra z nieskończonościa, Warszawa 1962.

Rasiowa H., Wstęp do matematyki współczesnej, Warszawa 1984.

Smullyan R., Szatan, Cantor i nieskończoność, Warszawa 2005.

Tatarkiewicz W., Historia filozofii, t. 1-3, Warszawa 1990.

Trzęsicki K., Leibnizjańskie inspiracje informatyki, „Filozofia Nauki” 2006, nr 3 (55), s. 21-48. 